\title{
EGY INNOVÁCIÓS KÖR INNOVÁCIÓS PORTFÓLIÓI
}

\section{Szerzők:}

Dr. Mező Katalin

Debreceni Egyetem

Dr. Mező Ferenc

Eszterházy Károly Egyetem

\section{Lektorok:}

Prof. Dr. Demetrovics János akadémikus MTA SZTAKI

Dr. Koncz István

Professzorok az Európai Magyarországért

Egyesület

\section{Első szerző e-mail címe:}

kata.mezo1@gmail.com

Mező Katalin és Mező Ferenc (2018): Egy innovációs kör innovációs portfóliói. Különleges Bánásmód, IV. évf., 2018/2. szám, 69-76. DOI 10.18458/KB.2018.2.69

\begin{abstract}
Absztrakt
A magyar $\mathrm{K}+\mathrm{F}$ Stúdió Kft. Innovációs Köre egy fiatal felnőtteknek szóló speciális tehetséggondozó program, mely a Nemzeti Tehetség Program egyik pályázata keretében valósult meg (pályázati azonosító: NTP-PKTF-17-0017). E program eredményeinek egyike egy e-könyv, mely $(n=42)$ fiatal felnőtt innovációs portfólióit tartalmazza. E cikk ennek a programnak és kiadványnak a tapasztalatait összegzi.
\end{abstract}

Kulcszavak: innováció, tehetség

Diszciplinák: pedagógia, pszichológia

\section{Abstract \\ INNOVATION PORTFOLIOS OF AN INNOVATION CLUB}

The Innovation Club of the Hungarian $\mathrm{K}+\mathrm{F}$ Studio Ltd. is a special talent development program for young adults, which program was realized in frame of a project of National Talent Program (project code is NTP-PKTF-17-0017). One of the results of these program project is an e-book, which contains young adults' $(\mathrm{n}=42)$ innovational portfolios. This article summarizes the experiences of these program and book.

Keywords: innovation, talent

Disciplines: pedagogy, psychology

Az Emberi Erőforrások Minisztériuma (mint támogató), Emberi Erőforrás Támogatáskezelő (mint lebonyolító) és a Nemzeti Tehetség Program által meghirdetett „, A hazai és határon túli pályakezdö, kiemelkedöen tehetséges fiatalok példaértékü innovációinak és társadalmi 
felelösségvállalásuk erösitésének támogatása” program egyik nyertes pályázata a $\mathrm{K}+\mathrm{F}$ Stúdió „Innovátor Kör” címü programja (pályázati azonosító: NTP-PKTF-17-0017).

Az „Innovációs Kör” célcsoportját 16-35 éves fiatalok alkották. A foglalkozás-sorozat iránti nagy érdeklődés miatt a pályázatban vállalt (10 hazai és 10 határon túli magyar tehetség) létszámokhoz képest több (összesen 60) fiatal számára vált lehetővé a bekapcsolódás a következők szerint: a pályázatban foglaltaknak megfelelően 10 hazai fiatal vett részt az „Innovációs Kör” foglalkozásain, s 10 határon túli fiatal bevonása történt meg. Ezen kívül 40 hazai fiatalnak volt lehetősége arra, hogy innovációs portfóliókat tartalmazó kiadványban ők is közzé tehessék felvetéseiket - közülük végül 32 fó élt ezzel a lehetőséggel. A program végére létrejött kiadványban (Mező F. és Mező L. D., 2018) végül 42 fiatal tehetség írását tehettük közzé. A beválogatás módszere: interjú, ami során a jelentkező (e program sikeres teljesítéséhez szükséges) intellektusáról, kreativitásáról, motiváltságáról igyekeztünk képet alkotni.

A program lényege dióhéjban: a résztvevők számára szervezett innovációval kapcsolatos foglalkozássorozat során a fiatalok innovációs portfóliót hoztak létre, amelyek lektorált, ISBN számmal rendelkező kiadványban (Mező F. és Mező L. D., 2018) jelentek meg, s lettek ingyenesen hozzáférhetők, annak érdekében, hogy a fiatal tehetségek számára a nyilvánosság biztosítva legyen.

A 30 óra időtartamú „Innovációs Kör” címü egyéni, páros, kiscsoportos és csoportos munkaformákat egyaránt alkalmazó interaktív foglalkozássorozatban 10 bevont fiatal, s 2 programvezető/mentor vett részt. A foglalkozássorozat célja egyrészt a bevont fiatalok innovációval, innovációs lehetőségekkel kapcsolatos érzékenyítése volt, másrészt (a kiegészítő programok révén) konferencia prezentációs, szerkesztett kiadványban történő publikációs lehetőségek biztosítása révén „élő helyzetben” gyakorolhatták kommunikációs készségeiket, $\mathrm{s}$ mutathatták be egyben innovációs felvetéseiket a fiatalok. A foglalkozássorozat tematikája:

1. Innovációs esetfeldolgozás és az innovációs folyamat modellezése

2. Önismereti tréning az ön-menedzselés jegyében

3. Az innovációs környezet sajátosságai és résztvevői

4. Kreatív kapcsolatalakítási stratégiák - határon innen és túl

5. Kreativitásfejlesztő tréning

6. Vezetöi készségfejlesztő tréning

7. Kommunikációs és konfliktuskezelési tréning

8. Innováció és társadalmi felelősségvállalás

9. Innováció és jogvédelem

10. A program zárása

Kiegészítő programként vállalkozásfejlesztéssel kapcsolatos mühelymunkában, külföldi trénerek által tartott innovációs tréningen, önálló prezentációk tartásával nemzetközi konferenciákon vettek részt a bevont fiatalok. Az innovációval kapcsolatos kisfilm készült (elérhető a www.kpluszf.com weblapon keresztül). A kiegészítő programok esetében:

a) a workshop során nagy érdeklődést keltett az „Innováció és vállalkozás létrehozása és fejlesztése" címü program;

b) a külföldi trénerek bevonásával megvalósult „Innovatio tréning” segített az európai perspektívába helyezni az innovációk jelentőségét;

c) poszterkiállításra nyílt lehetőség a III. nemzetközi Interdiszciplináris Konferencián;

d) a nyilvánosság biztosítására és az előadói rutin megszerzésére adott továbbá lehetőséget a fiataloknak a XV. és XVI. Nemzetközi PhD Konferenciákon, a III. Nemzetközi Interdiszciplináris Konferencián és a Fókuszban az innováció konferencián történő részvétel. 
A programmal kapcsolatos publikációk:

- Mező Ferenc és Mező Katalin (2017): Az innovátorok következő generációi felé - a K+F Stúdió tehetséggondozó programja. Különleges Bánásmód, III. évf. 2017/3. szám, 111-113.

- Mező Ferenc és Mező Katalin (2018a): Az innovációra nevelés: a felnőttkori tehetséggondozás egyik sarokpontja. Tehetség, XXVI. évfolyam 2018/2 szám, 14-15.

- Mező Ferenc és Mező Katalin (2018b): Innováció és tehetséggondozás - A K+F Stúdió Innovátor Köre. Különleges Bánásmód, IV. évf., 2018/1. szám, 85-88.

- Mező Ferenc és Mező Lilla Dóra (szerk.)(2018): Innovációs portfóliók. K+F Stúdió Kft., Debrecen. Letöltés: 2018. június 30. Web: www.kpluszf.com

Ez utóbbi, a program végére összeállt innovációs portfóliókat összegző kiadványban (Mező F. és Mező L.D., 2018; lásd: 1. ábra), a Szerzők (a bevont fiatalok és kortársaik) saját innovációikat mutatják be vázlatosan.

1. ábra: a kiadvány boritója (Mezö F. és Mezö L.D., 2018)

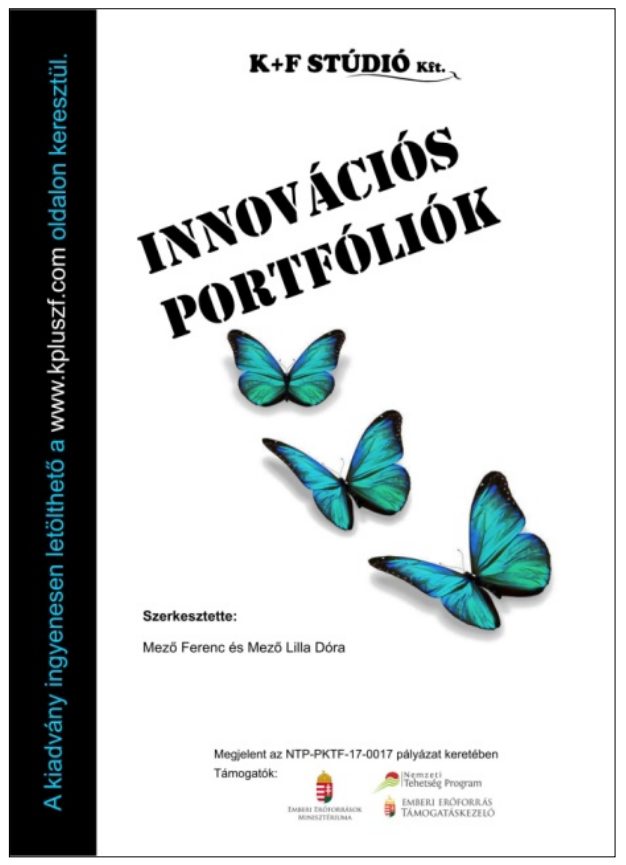

Az innovációs portfóliók elkészítésekor (a szerzői és egyéb jogok védelme érdekében) szándékosan nem az lett kérve a Szerzőktől, hogy részletesen mutassák be innovációkra vonatkozó ötleteiket és elképzeléseiket. A portfóliókban közreadott információkat tekintve lényeges volt, hogy a fiatal szerzők óvatosan fogalmazzanak - ötleteik védelme, innovációkkal kapcsolatos jogaik biztosítása érdekében. A portfóliók így is elérték céljukat: alkotásuk során Szerzőik az innovációkkal kapcsolatos tudást kaptak, ötleteket vetettek fel, s remélhetőleg sikerült arra érzékenyíteni őket, hogy merjenek innovatívak lenni! Mint a tehetséggondozásban sokszor megfigyelhető, itt is érvényesült, hogy fontosabb a célhoz vezető útnál, maga az út, ami odavezet. A kiadványban közreadott innovációk kidolgozottsága is változatos. A Szerzők között volt, aki komolyan vette az innovációs portfólió alkotását, s volt olyan is, aki inkább egyfajta szellemi játéknak tekintette azt. 
A témaválasztás igen sokszínű volt: az okos, illetve önvezető autókkal kapcsolatban alkotott innovációs portfólióktól - lásd: Csige Zoltán (2018), Mészáros Bence (2018), Som Petra (2018) - a szórakoztató utazást szolgáló kapaszkodójáték lehetőséget felevetőkön át (lásd: Geng Julián, 2018) a szórakoztató elektronikát célzó alkotásokig - lásd: Psenák Péter (2018) öntanító gitárra, valamint Vas János (2018) videojátékokra vonatkozó műveit - terjedt a fiatalok által felevetett ötletek egy része.

Mások az „otthon” világa felől vetettek fel innovatív ötleteket portfólióikban. Mező Lilla Dóra (2018) okos házakkal, Járomi Dávid (2018) okos ablakkal, Faragó Zsófia (2018) tetőcserepekkel, Mező Péter Dániel (2018) smart fallal, Horváth Lili Dóra (2018) ruhásszekrénnyel kapcsolatos portfóliói sorolhatók ebbe a kategóriába. A szükebb-tágabb értelemben vett otthon tisztaságával kapcsolatban születtek innovációs portfóliók - ilyenek: Szabó László (2018) szőnyegtisztítással, Veresné Farkas Rita (2018) ruhaszárítással, illetve Roskó Tibor (2018) okos köztéri hulladékgyüjtőkkel kapcsolatos felvetései.

A smart technológia további lehetőségeire fókuszált Horváth Viktória (2018) okos pénztárcával, Juhász Alexandra (2018) okos virágcseréppel, Sipos Péter (2018) telefonokkal, Sviatkó Sándor (2018) smart fejhallgatóval, Varga-Szlávik Ildikó (2018) okos ceruzával kapcsolatos müveikben.

A ruházkodás témájától kezdve keresztül egy másik gondolati ív húzható Horváth Zoltán (2018) elektromosságot termelő zoknira, Ligeti Ádám (2018) okos cipőtalpbetétre, Váraljai Szabolcs (2018) sportcipőkre vonatkozó javaslataitól a házi kedvencek egészségcélú öltöztetését is célzó kutya napszemüveg en át - lásd: Séra Bianka Zsófia (2018) - a szépség és egészség központú innovációs ötletekig. Ez utóbbi csoportba tartozik például Majoros Dóra (2018) orvosi fogfehérítéssel, Márton Fanni (2018) lézeres szőrtelenítéssel, Palásti Lilla (2018) hajegyenesítéssel és Papp-Kátay Zsanett (2018) bőrápolással, Rottenstein Fanni (2018) elalvást segítő karkötővel, Lázár Dávid (2018) lelki egészséget óvó eszközzel és Varga Endre (2018) „Siker tréning szoftver” fejlesztésével kapcsolatos innovációs portfóliója.

Az oktatás és kommunikáció témakörén belül Raminczki Anita (2018) felelés és szavazás, Sére Bianka Zsófia (2018) oktatás, Szabó Gergely (2018) TeachUp, Szabó János (2018) tehetségkutatás, Szász Edmond (2018) távoktatás, Szombati Márk (2018) okos órarend és Reiner Andor Gábor (2018) VR szemüvegek nem szórakoztató ipari célú (például: oktatási, medicinális) felhasználása terén alkotott innovációs portfóliókat.

Kontsikné Gerendás Anikó (2018) az elveszett gyermek cumik keresésére fordított idő csökkentésére alkotott világító, jelző cumi ötletét veti fel írásában. A gyermek cumik világától juthatunk el egy újabb gondolati íven az étkezés gondolatköréig. Koczka-Nagy Barbara (2018) babaételekkel kapcsolatos gondolataitól az étkezéssel más életkorokban is foglalkozó megoldáskeresésig terjedő innovációs ötleteket vázolt fel Egri-Szabó Éva (2018) és Gönczi Julianna (2018). Virág Ádám (2018) pedig egészen széles látókörről és társadalmi érzékenységről árulkodó módon ragadta meg a témát, mikor innovációs ötlete egyaránt megoldást kínál a hátrányos helyzetü és megváltozott munkaképességü emberek foglalkoztatásának szociális szövetkezetek általi elősegítése és a helyi termékek fogyasztásának ösztönzése problémájára.

A pályázat keretében tehát létrejött egy bevezető tanulmányt (Mező, 2018) és 42 innovációs portfóliót tartalmazó kiadvány. E portfóliók adatai:

Csige Zoltán (2018): Innovációs portfólió önvezető autókkal kapcsolatban. In: Mező Ferenc és Mező Lilla Dóra (szerk.): Innovációs portfóliók. K+F Stúdió Kft., Debrecen. 17-21.

Egri-Szabó Éva (2018): Innovációs portfólió étkezéssel kapcsolatban. In: Mező Ferenc és Mező Lilla Dóra (szerk.): Innovációs portfóliók. K+F Stúdió Kft., Debrecen. 23-26.

Faragó Zsófia (2018): Innovációs portfólió tetőcserepekkel kapcsolatban. In: Mező Ferenc és Mező Lilla Dóra (szerk.): Innovációs portfóliók. K+F Stúdió Kft., Debrecen. 27-32.

Geng Julián (2018): Innovációs portfólió kapaszkodójátékkal kapcsolatban. In: Mező Ferenc és Mező Lilla Dóra (szerk.): Innovációs portfóliók. K+F Stúdió Kft., Debrecen. 33-34. 
Gönczi Julianna (2018): Innovációs portfólió ecettel kapcsolatban. In: Mező Ferenc és Mező Lilla Dóra (szerk.): Innovációs portfóliók. K+F Stúdió Kft., Debrecen. 35-40.

Horváth Lili Dóra (2018): Innovációs portfólió ruhásszekrénnyel kapcsolatban. In: Mező Ferenc és Mező Lilla Dóra (szerk.): Innovációs portfóliók. K+F Stúdió Kft., Debrecen. 41.

Horváth Viktória (2018): Innovációs portfólió okos pénztárcával kapcsolatban. In: Mező Ferenc és Mező Lilla Dóra (szerk.): Innovációs portfóliók. K+F Stúdió Kft., Debrecen. 43-47.

Horváth Zoltán (2018): Innovációs portfólió elektromossággal kapcsolatban. In: Mező Ferenc és Mező Lilla Dóra (szerk.): Innovációs portfóliók. K+F Stúdió Kft., Debrecen. 49-52.

Járomi Dávid (2018): Innovációs portfólió okos ablakkal kapcsolatban. In: Mező Ferenc és Mező Lilla Dóra (szerk.): Innovációs portfóliók. K+F Stúdió Kft., Debrecen. 53-54.

Juhász Alexandra (2018): Innovációs portfólió okos virágcseréppel kapcsolatban. In: Mező Ferenc és Mező Lilla Dóra (szerk.): Innovációs portfóliók. K+F Stúdió Kft., Debrecen. 55.

Koczka-Nagy Barbara (2018): Innovációs portfólió babaételekkel kapcsolatban. In: Mezö Ferenc és Mező Lilla Dóra (szerk.): Innovációs portfóliók. K+F Stúdió Kft., Debrecen. 57-60.

Kontsikné Gerendás Anikó (2018): Innovációs portfólió gyermekek cumijával kapcsolatban. In: Mező Ferenc és Mező Lilla Dóra (szerk.): Innovációs portfóliók. K+F Stúdió Kft., Debrecen. 61-64.

Lázár Dávid (2018): Innovációs portfólió pszichológiai segédeszközzel kapcsolatban. In: Mező Ferenc és Mező Lilla Dóra (szerk.): Innovációs portfóliók. K+F Stúdió Kft., Debrecen. 65-68.

Ligeti Ádám (2018): Innovációs portfólió okos cipőtalpbetéttel kapcsolatban. In: Mező Ferenc és Mező Lilla Dóra (szerk.): Innovációs portfóliók. K+F Stúdió Kft., Debrecen. 69-75.

Majoros Dóra (2018): Innovációs portfólió orvosi fogfehérítéssel kapcsolatban. In: Mező Ferenc és Mező Lilla Dóra (szerk.): Innovációs portfóliók. K+F Stúdió Kft., Debrecen. 77-81.

Márton Fanni (2018): Innovációs portfólió lézeres szőrtelenítéssel kapcsolatban. In: Mező Ferenc és Mező Lilla Dóra (szerk.): Innovációs portfóliók. K+F Stúdió Kft., Debrecen. 83-87.

Mező Lilla Dóra (2018): Innovációs portfólió okos házakkal kapcsolatban. In: Mező Ferenc és Mező Lilla Dóra (szerk.): Innovációs portfóliók. K+F Stúdió Kft., Debrecen. 89-92.

Mező Péter Dániel (2018): Innovációs portfólió Smart-fallal kapcsolatban. In: Mező Ferenc és Mező Lilla Dóra (szerk.): Innovációs portfóliók. K+F Stúdió Kft., Debrecen. 93-96.

Mészáros Bence (2018): Innovációs portfólió önvezető autókkal kapcsolatban. In: Mező Ferenc és Mező Lilla Dóra (szerk.): Innovációs portfóliók. K+F Stúdió Kft., Debrecen. 97-99.

Palásti Lilla (2018): Innovációs portfólió hajegyenesítéssel kapcsolatban. In: Mező Ferenc és Mező Lilla Dóra (szerk.): Innovációs portfóliók. K+F Stúdió Kft., Debrecen. 101-103.

Papp-Kátay Zsanett (2018): Innovációs portfólió bőrápolással kapcsolatban. In: Mező Ferenc és Mező Lilla Dóra (szerk.): Innovációs portfóliók. K+F Stúdió Kft., Debrecen. 105-109.

Psenák Péter (2018): Innovációs portfólió öntanító gitárral kapcsolatban. In: Mező Ferenc és Mező Lilla Dóra (szerk.): Innovációs portfóliók. K+F Stúdió Kft., Debrecen. 111-114.

Raminczki Anita (2018): Innovációs portfólió feleléssel és szavazással kapcsolatban. In: Mező Ferenc és Mező Lilla Dóra (szerk.): Innovációs portfóliók. K+F Stúdió Kft., Debrecen. 115118.

Reiner Andor Gábor (2018): Innovációs portfólió VR szemüvegek szórakoztatóiparon kívüli felhasználásával kapcsolatban. In: Mező Ferenc és Mező Lilla Dóra (szerk.): Innovációs portfóliók. K+F Stúdió Kft., Debrecen. 119-122.

Roskó Tibor (2018): Innovációs portfólió okos köztéri hulladékgyüjtőkkel kapcsolatban. In: Mező Ferenc és Mező Lilla Dóra (szerk.): Innovációs portfóliók. K+F Stúdió Kft., Debrecen. 123128.

Rottenstein Fanni (2018): Innovációs portfólió elalvást segítő karkötővel kapcsolatban. In: Mező Ferenc és Mező Lilla Dóra (szerk.): Innovációs portfóliók. K+F Stúdió Kft., Debrecen. 129.

Sándor Hajnalka (2018): Innovációs portfólió oktatással kapcsolatban. In: Mező Ferenc és Mező Lilla Dóra (szerk.): Innovációs portfóliók. K+F Stúdió Kft., Debrecen. 131-134.

Séra Bianka Zsófia (2018): Innovációs portfólió kutya napszemüveggel kapcsolatban. In: Mező Ferenc és Mező Lilla Dóra (szerk.): Innovációs portfóliók. K+F Stúdió Kft., Debrecen. 135137.

Sipos Péter (2018): Innovációs portfólió telefonokkal kapcsolatban. In: Mező Ferenc és Mező Lilla Dóra (szerk.): Innovációs portfóliók. K+F Stúdió Kft., Debrecen. 139-140.

Som Petra (2018): Innovációs portfólió okos autókkal kapcsolatban. In: Mező Ferenc és Mező Lilla Dóra (szerk.): Innovációs portfóliók. K+F Stúdió Kft., Debrecen. 141-144.

Sviatkó Sándor (2018): Innovációs portfólió smart fejhallgatóval kapcsolatban. In: Mező Ferenc és Mező Lilla Dóra (szerk.): Innovációs portfóliók. K+F Stúdió Kft., Debrecen. 145. 
Szabó Gergely (2018): Innovációs portfólióTeachUp-pal kapcsolatban. In: Mező Ferenc és Mező Lilla Dóra (szerk.): Innovációs portfóliók. K+F Stúdió Kft., Debrecen. 147-154.

Szabó János (2018): Innovációs portfólió tehetségkutatással kapcsolatban. In: Mező Ferenc és Mező Lilla Dóra (szerk.): Innovációs portfóliók. K+F Stúdió Kft., Debrecen. 155-160.

Szabó László (2018): Innovációs portfólió szőnyeg tisztítással kapcsolatban. In: Mező Ferenc és Mező Lilla Dóra (szerk.): Innovációs portfóliók. K+F Stúdió Kft., Debrecen. 161-165.

Szász Edmond (2018): Innovációs portfólió távoktatással kapcsolatban. In: Mező Ferenc és Mező Lilla Dóra (szerk.): Innovációs portfóliók. K+F Stúdió Kft., Debrecen. 167-170.

Szombati Márk (2018): Innovációs portfólió okos órarenddel kapcsolatban. In: Mező Ferenc és Mező Lilla Dóra (szerk.): Innovációs portfóliók. K+F Stúdió Kft., Debrecen. 171-173.

Varga Endre: (2018): Innovációs portfólió siker elérésével kapcsolatban. In: Mező Ferenc és Mező Lilla Dóra (szerk.): Innovációs portfóliók. K+F Stúdió Kft., Debrecen. 175-180.

Varga-Szlávik Ildikó (2018): Innovációs portfólió okos ceruzával kapcsolatban. In: Mező Ferenc és Mező Lilla Dóra (szerk.): Innovációs portfóliók. K+F Stúdió Kft., Debrecen. 181-187.

Vas János (2018): Innovációs portfólió videojátékokkal kapcsolatban. In: Mező Ferenc és Mező Lilla Dóra (szerk.): Innovációs portfóliók. K+F Stúdió Kft., Debrecen. 189-194.

Váraljai Szabolcs (2018): Innovációs portfólió sportcipőkkel kapcsolatban. In: Mező Ferenc és Mező Lilla Dóra (szerk.): Innovációs portfóliók. K+F Stúdió Kft., Debrecen. 195-198.

Virág Ádám (2018): Innovációs portfólió helyi termékekkel kapcsolatban. In: Mező Ferenc és Mezö Lilla Dóra (szerk.): Innovációs portfóliók. K+F Stúdió Kft., Debrecen. 199-205.

Veresné Farkas Rita (2018): Innovációs portfólió ruhaszárítással kapcsolatban. In: Mező Ferenc és Mező Lilla Dóra (szerk.): Innovációs portfóliók. K+F Stúdió Kft., Debrecen. 207-211.

Az írásbeli publikációkon túl az alábbi konferenciákon került bemutatásra az Innovációs Kör:

- II. Különleges Bánásmód Konferencián, 2017-ben, Hajdúböszörményben.

- Professzorok az Európai Magyarországért Egyesület XV. Nemzetközi Tudományos Konferenciáján 2017-ben, Budapesten.

- Professzorok az Európai Magyarországért Egyesület XVI. Nemzetközi Tudományos Konferenciáján 2018-ban, Budapesten.

- III. Nemzetközi Interdiszciplináris Konferencián 2018-ban, Debrecenben.

- A Fókuszban az innováció konferencián 2018-ban, Debrecenben.

Az utóbbi négy rendezvényen a programba bevont fiatalok is részt vettek előadóként.

Mindezen túl e fiatalok 10 rövidfilm létrehozásában müködtek közre, melyek stáblistájában rendezőasszisztensként is fel vannak tüntetve (a filmek megtekinthetők a K+F Stúdió Kft. www.kpluszf.com honlapján keresztül).

Összességében egy produktumokban gazdag, innovációra tanító és ösztönző programról van tehát szó, amely nem valósulhatott volna meg a Nemzeti Tehetség Program támogatása nélkül, amit ezúton is köszönünk!

\section{Irodalom}

Csige Zoltán (2018): Innovációs portfólió önvezető autókkal kapcsolatban. In: Mező Ferenc és Mező Lilla Dóra (szerk.): Innovációs portfóliók. K+F Stúdió Kft., Debrecen. 17-21.

Egri-Szabó Éva (2018): Innovációs portfólió étkezéssel kapcsolatban. In: Mező Ferenc és Mező Lilla Dóra (szerk.): Innovációs portfóliók. K+F Stúdió Kft., Debrecen. 23-26.

Faragó Zsófia (2018): Innovációs portfólió tetőcserepekkel kapcsolatban. In: Mező Ferenc és Mező Lilla Dóra (szerk.): Innovációs portfóliók. K+F Stúdió Kft., Debrecen. 27-32.

Geng Julián (2018): Innovációs portfólió kapaszkodójátékkal kapcsolatban. In: Mező Ferenc és Mező Lilla Dóra (szerk.): Innovációs portfóliók. K+F Stúdió Kft., Debrecen. 33-34.

Gönczi Julianna (2018): Innovációs portfólió ecettel kapcsolatban. In: Mező Ferenc és Mező Lilla Dóra (szerk.): Innovációs portfóliók. K+F Stúdió Kft., Debrecen. 35-40. 
Horváth Lili Dóra (2018): Innovációs portfólió ruhásszekrénnyel kapcsolatban. In: Mező Ferenc és Mező Lilla Dóra (szerk.): Innovációs portfóliók. K+F Stúdió Kft., Debrecen. 41.

Horváth Viktória (2018): Innovációs portfólió okos pénztárcával kapcsolatban. In: Mező Ferenc és Mező Lilla Dóra (szerk.): Innovációs portfóliók. K+F Stúdió Kft., Debrecen. 4347.

Horváth Zoltán (2018): Innovációs portfólió elektromossággal kapcsolatban. In: Mező Ferenc és Mező Lilla Dóra (szerk.): Innovációs portfóliók. K+F Stúdió Kft., Debrecen. 49-52.

Járomi Dávid (2018): Innovációs portfólió okos ablakkal kapcsolatban. In: Mező Ferenc és Mező Lilla Dóra (szerk.): Innovációs portfóliók. K+F Stúdió Kft., Debrecen. 53-54.

Juhász Alexandra (2018): Innovációs portfólió okos virágcseréppel kapcsolatban. In: Mező Ferenc és Mező Lilla Dóra (szerk.): Innovációs portfóliók. K+F Stúdió Kft., Debrecen. 55.

Koczka-Nagy Barbara (2018): Innovációs portfólió babaételekkel kapcsolatban. In: Mező Ferenc és Mező Lilla Dóra (szerk.): Innovációs portfóliók. K+F Stúdió Kft., Debrecen. 5760.

Kontsikné Gerendás Anikó (2018): Innovációs portfólió gyermekek cumijával kapcsolatban. In: Mező Ferenc és Mező Lilla Dóra (szerk.): Innovációs portfóliók. K+F Stúdió Kft., Debrecen. 61-64.

Lázár Dávid (2018): Innovációs portfólió pszichológiai segédeszközzel kapcsolatban.. In: Mező Ferenc és Mező Lilla Dóra (szerk.): Innovációs portfóliók. K+F Stúdió Kft., Debrecen. 65-68.

Ligeti Ádám (2018): Innovációs portfólió okos cipőtalpbetéttel kapcsolatban. In: Mező Ferenc és Mező Lilla Dóra (szerk.): Innovációs portfóliók. K+F Stúdió Kft., Debrecen. 6975.

Majoros Dóra (2018): Innovációs portfólió orvosi fogfehérítéssel kapcsolatban. In: Mező Ferenc és Mező Lilla Dóra (szerk.): Innovációs portfóliók. K+F Stúdió Kft., Debrecen. 7781.

Márton Fanni (2018): Innovációs portfólió lézeres szőrtelenítéssel kapcsolatban. In: Mező Ferenc és Mező Lilla Dóra (szerk.): Innovációs portfóliók. K+F Stúdió Kft., Debrecen. 8387.

Mező Ferenc (2018): Innovátor Kör. In: Mező Ferenc és Mező Lilla Dóra (szerk.): Innovációs portfóliók. K+F Stúdió Kft., Debrecen. 13-16.

Mező Ferenc és Mező Katalin (2017): Az innovátorok következő generációi felé - a K+F Stúdió tehetséggondozó programja. Különleges Bánásmód, III. évf. 2017/3. szám, 111-113.

Mező Ferenc és Mező Katalin (2018a): Az innovációra nevelés: a felnőttkori tehetséggondozás egyik sarokpontja. Tehetség, XXVI. évfolyam 2018/2 szám, 14-15.

Mező Ferenc és Mező Katalin (2018b): Innováció és tehetséggondozás - A K+F Stúdió Innovátor Köre. Különleges Bánásmód, IV. évf. , 2018/1. szám, 85-88.

Mező Ferenc és Mező Lilla Dóra (2018): Innovációs portfóliók. K+F Stúdió Kft., Debrecen. Letöltés: 2018. június 30. Web: www.kpluszf.com.

Mező Lilla Dóra (2018): Innovációs portfólió okos házakkal kapcsolatban. In: Mező Ferenc és Mező Lilla Dóra (szerk.): Innovációs portfóliók. K+F Stúdió Kft., Debrecen. 89-92.

Mező Péter Dániel (2018): Innovációs portfólió Smart-fallal kapcsolatban. In: Mező Ferenc és Mező Lilla Dóra (szerk.): Innovációs portfóliók. K+F Stúdió Kft., Debrecen. 93-96.

Mészáros Bence (2018): Innovációs portfólió önvezető autókkal kapcsolatban. In: Mező Ferenc és Mező Lilla Dóra (szerk.): Innovációs portfóliók. K+F Stúdió Kft., Debrecen. 9799.

Palásti Lilla (2018): Innovációs portfólió hajegyenesítéssel kapcsolatban. In: Mező Ferenc és Mező Lilla Dóra (szerk.): Innovációs portfóliók. K+F Stúdió Kft., Debrecen. 101-103.

Papp-Kátay Zsanett (2018): Innovációs portfólió bőrápolással kapcsolatban. In: Mező Ferenc és Mező Lilla Dóra (szerk.): Innovációs portfóliók. K+F Stúdió Kft., Debrecen. 105-109. 
Psenák Péter (2018): Innovációs portfólió öntanító gitárral kapcsolatban. In: Mező Ferenc és Mező Lilla Dóra (szerk.): Innovációs portfóliók. K+F Stúdió Kft., Debrecen. 111-114.

Raminczki Anita (2018): Innovációs portfólió feleléssel és szavazással kapcsolatban. In: Mező Ferenc és Mező Lilla Dóra (szerk.): Innovációs portfóliók. K+F Stúdió Kft., Debrecen. 115-118.

Reiner Andor Gábor (2018): Innovációs portfólió VR szemüvegek szórakoztatóiparon kívüli felhasználásával kapcsolatban. In: Mező Ferenc és Mező Lilla Dóra (szerk.): Innovációs portfóliók. K+F Stúdió Kft., Debrecen. 119-122.

Roskó Tibor (2018): Innovációs portfólió okos köztéri hulladékgyüjtőkkel kapcsolatban. In: Mező Ferenc és Mező Lilla Dóra (szerk.): Innovációs portfóliók. K+F Stúdió Kft., Debrecen. 123-128.

Rottenstein Fanni (2018): Innovációs portfólió elalvást segítő karkötővel kapcsolatban. In: Mező Ferenc és Mező Lilla Dóra (szerk.): Innovációs portfóliók. K+F Stúdió Kft., Debrecen. 129.

Sándor Hajnalka (2018): Innovációs portfólió oktatással kapcsolatban. In: Mező Ferenc és Mező Lilla Dóra (szerk.): Innovációs portfóliók. K+F Stúdió Kft., Debrecen. 131-134.

Séra Bianka Zsófia (2018): Innovációs portfólió kutya napszemüveggel kapcsolatban. In: Mező Ferenc és Mező Lilla Dóra (szerk.): Innovációs portfóliók. K+F Stúdió Kft., Debrecen. 135-137.

Sipos Péter (2018): Innovációs portfólió telefonokkal kapcsolatban. In: Mező Ferenc és Mező Lilla Dóra (szerk.): Innovációs portfóliók. K+F Stúdió Kft., Debrecen. 139-140.

Som Petra (2018): Innovációs portfólió okos autókkal kapcsolatban. In: Mező Ferenc és Mező Lilla Dóra (szerk.): Innovációs portfóliók. K+F Stúdió Kft., Debrecen. 141-144.

Sviatkó Sándor (2018): Innovációs portfólió smart fejhallgatóval kapcsolatban. In: Mező Ferenc és Mező Lilla Dóra (szerk.): Innovációs portfóliók. K+F Stúdió Kft., Debrecen. 145.

Szabó Gergely (2018): Innovációs portfólióTeachUp-pal kapcsolatban. In: Mező Ferenc és Mező Lilla Dóra (szerk.): Innovációs portfóliók. K+F Stúdió Kft., Debrecen. 147-154.

Szabó János (2018): Innovációs portfólió tehetségkutatással kapcsolatban. In: Mező Ferenc és Mező Lilla Dóra (szerk.): Innovációs portfóliók. K+F Stúdió Kft., Debrecen. 155-160.

Szabó László (2018): Innovációs portfólió szőnyeg tisztítással kapcsolatban. In: Mező Ferenc és Mező Lilla Dóra (szerk.): Innovációs portfóliók. K+F Stúdió Kft., Debrecen. 161-165.

Szász Edmond (2018): Innovációs portfólió távoktatással kapcsolatban. In: Mező Ferenc és Mező Lilla Dóra (szerk.): Innovációs portfóliók. K+F Stúdió Kft., Debrecen. 167-170.

Szombati Márk (2018): Innovációs portfólió okos órarenddel kapcsolatban. In: Mező Ferenc és Mező Lilla Dóra (szerk.): Innovációs portfóliók. K+F Stúdió Kft., Debrecen. 171-173.

Varga Endre: (2018): Innovációs portfólió siker elérésével kapcsolatban. In: Mező Ferenc és Mező Lilla Dóra (szerk.): Innovációs portfóliók. K+F Stúdió Kft., Debrecen. 175-180.

Varga-Szlávik Ildikó (2018): Innovációs portfólió okos ceruzával kapcsolatban. In: Mező Ferenc és Mező Lilla Dóra (szerk.): Innovációs portfóliók. K+F Stúdió Kft., Debrecen. 181-187.

Vas János (2018): Innovációs portfólió videojátékokkal kapcsolatban. In: Mező Ferenc és Mező Lilla Dóra (szerk.): Innovációs portfóliók. K+F Stúdió Kft., Debrecen. 189-194.

Váraljai Szabolcs (2018): Innovációs portfólió sportcipőkkel kapcsolatban. In: Mező Ferenc és Mező Lilla Dóra (szerk.): Innovációs portfóliók. K+F Stúdió Kft., Debrecen. 195-198.

Virág Ádám (2018): Innovációs portfólió helyi termékekkel kapcsolatban. In: Mező Ferenc és Mező Lilla Dóra (szerk.): Innovációs portfóliók. K+F Stúdió Kft., Debrecen. 199-205.

Veresné Farkas Rita (2018): Innovációs portfólió ruhaszárítással kapcsolatban. In: Mező Ferenc és Mező Lilla Dóra (szerk.): Innovációs portfóliók. K+F Stúdió Kft., Debrecen. 207-211. 